\title{
KULINERI OLAHAN NENAS BAGI KELOMPOK MASYARAKAT DESA DEMA KALIMANTAN BARAT
}

\author{
Processed Pineapple Culinary Society For Rural Dema West Kalimantan
}

\author{
Agato $^{1)}$, Kardison Lumban Batu ${ }^{1)}$ \\ Politeknik Negeri Pontianak, Jurusan Teknologi Pertanian dan Administrasi Bisnis, \\ Kalimantan Barat ${ }^{1}$
}

\begin{abstract}
Commodity pineapples as Dema local village is a potential that can be developed in the economic boom Dema village. Village Community Dema prefer to sell fresh pineapple because of a lack of skills knowlegde and pineapple processing into processed food products are attractive and economic value. Community service activities become a place of education and improvement of skills appropriate for rural areas. The method of implementation of community service priority to simplification in the delivery of materials and focus on improving skills. Provide information on post harvest technology pineapples, business opportunities and training in the processing of processed pineapple pineapples as kulineri expected to form a village community Dema creative, innovative and productive in the local commodity potential overreach. Efforts to improve the quality of Human Resources Dema village certainly make an impact on the improvement of human development index Dema village. Results from community service activities that the villagers of Dema skilled make kulineri processed pineapples were taught when activity.
\end{abstract}

Keywords: processed pineapple, pineapple post-harvest, human resources

\begin{abstract}
ABSTRAK
Nenas sebagai Komoditi lokal Desa Dema merupakan potensi yang dapat dikembangkan dalam peningkatan ekonomi masyarakat Desa Dema. Masyarakat Desa Dema lebih memilih menjual nenas segar karena kurangnya pegetahuan dan ketrampilan mengolah nenas menjadi produk pangan olahan yang menarik dan bernilai ekonomi. Kegiatan pengabdian kepada masyarakat menjadi wadah pendidikan dan peningkatan ketrampilan yang tepat bagi daerah pedesaan. Metode pelaksanaan pengabdian kepada masyarakat mengutamakan penyederhanaan dalam penyampaian materi dan fokus pada peningkatan ketrampilan. Memberikan informasi teknologi pasca panen nenas, peluang usaha dan pelatihan dalam mengolah nenas sebagai kulineri olahan nenas diharapkan dapat membentuk masyarakat Desa Dema yang kreatif, inovatif dan produktif dalam memperdayakan potensi komoditi lokal. Usaha meningkatkan kualitas Sumber Daya Manusia Desa Dema tentunya memberi pengaruh pada perbaikan indek pembangunan manusia Desa Dema. Hasil dari kegiatan pengabdian kepada masyarakat yaitu masyarakat Desa Dema yang terampil membuat kulineri olahan nenas yang diajarkan saat kegiatan.
\end{abstract}

Kata Kunci: kulineri olahan nenas, pasca panen nenas, sumber daya manusia

\section{PENDAHULUAN}

Kecamatan Anjongan merupakan sebuah kecamatan yang berada di Kabupaten Mempawah Kalimantan Barat. Kecamatan

Anjongan berjarak $\pm 38 \mathrm{~km}$ dari kota Pontianak dan memiliki luas $176,55 \mathrm{~km}^{2}$ atau 6,31\% luas Kabupaten Mempawah. 
Secara umum, proyeksi struktur ekonomi Kabupaten Mempawah pada lima tahun terakhir dominan pada sektor pertanian, yaitu rerata 27,12 \%. Kecamatan Anjongan sebagai bagian dari Kabupaten Mempawah berperan besar dalam menunjang perkembangan sektor pertanian Kabupaten Mempawah dengan memiliki bentangan hutan rakyat seluas 423 ha, perkebunan 1.604 ha, hutan negara 2.257 ha, lahan belum diusahakan 32 ha dan lain-lain 13.339 ha (Bapeda Kabupaten Pontinak, 2008). Komoditi pertanian yang banyak dikembangkan di Kecamatan Anjongan meliputi kelapa sawit, kelapa, nenas, padi dan palawija. Kecamatan Anjongan merupakan pemekaran dari Kecamatan Sungai Pinyuh yang meliputi Desa Anjongan Dalam, Anjongan Melanjar, Dema, Kepayang dan Pak Bulu. Desa Dema merupakan salah satu desa di kecamatan Anjongan yang memiliki adminitrasi desa yang baik, aktif dalam kegiatan pengembangan desa untuk meningkatkan kualitas manusia, kompak dalam kegiatan bermasyarakat dan giat dalam peningkatan sektor pertanian.

Kelompok ibu PKK dan kelompok tani merupakan organisasi di Desa Dema yang memiliki program kerja dan aktif berkegiatan. Begitu tingginya minat masyarakat Desa Dema dalam pengembangan diri yang tercermin pada aktivitas ibu-ibu PKK dan kelompok tani merupakan wadah yang baik dalam pengembangan potensi keahlian untuk pengolahan produk pangan komoditi lokal.

Kabupaten Mempawah merupakan Kabupaten di propinsi Kalimantan Barat yang mengembangkan kawasan holtikultura. Nanas menjadi salah satu komoditi yang dikembangkan pada kawasan holtikultura di Kabupaten Mempawah, yaitu jenis nanas queen. Terdapat 735 ha luas area lahan tanaman nanas di Kabupaten Mempawah dengan produksi 4,5 ton untuk setiap hektar (BPTP Kalimantan Barat, 2010). Pengembangan ini didukung oleh tanah dan agrokilmat yang cocok untuk tanaman nanas serta lahan kosong yang relatif luas di
Kabupaten Mempawah termasuk Desa Dema Kecamatan Anjongan. Nanas merupakan komoditi unggulan Desa Dema Kecamatan Anjongan selain padi. Sejauh ini masyarakat Desa Dema Kecamatan Anjongan lebih memilih cara praktis penanganan produk nanas, yaitu menjual nanas dipinggir jalan kepada pengepul atau langsung ke konsumen yang melewati jalan tempat mereka berjualan. Sebagai salah satu famili Bromeliaceae, buah nanas mengandung vitamin $\mathrm{C}$ dan vitamin A (retinol) masingmasing sebesar 24,0 miligram dan 39 miligram dalam setiap 100 gram bahan yang penting bagi tubuh (Sibuea, 1997). Usaha pengolahan nanas menjadi produk pangan belum dilakukan karena keterbatasan pengetahuan dalam pengolahan pasca panen nanas. Secara umum, begitu banyak variasi produk pasca panen nanas yang dapat diaplikasikan seperti sirup, keripik, selai dan produk nata (Rukmana dan Rahmat, 1997). Selain produk tersebut akan dikembangkan pula produk permen nanas yang dapat memberikan nuansa produk. Permen adalah produk yang dibuat dengan mendidihkan campuran gula dan air bersama dengan bahan pewarna dan pemberi rasa sampai tercapai kadar air kira-kira 3\%. Seni membuat permen dengan daya tahan yang memuaskan terletak pada pembuatan produk dengan kadar air minimum dan sedikit saja kecenderungan untuk mengkristal (Buckle dalam Nurwati, 2011). Pada kegiatan Pengabdian kepada masyarakat ini, mitra kerja yang dipilih yaitu ibu PKK, kelompok tani gotong royong dan sinar mandiri. Tiga kelompok organisasi masyarakat yang ada di Desa Dema ini dinilai dapat membantu keberlanjutan kegiatan dan mengembangkan ketrampilan pada kelompok lainnya.

\section{METODE PENELITIAN}

\section{Alat dan bahan}

Alat yang digunakan pada kegiatan pengabdian masyarakat meliputi: blender, oven, mixer, pisau, Loyang tipis, ayakan plastik, toples, cetakan kue basah, nampan plastik, baskom, sendok, garpu, panci 
pengukus dan perebus, kompor gas yang dilengkapi selang dan tabung gas, sutil, botol saus, teko ukur, kuali, talenan, serbet, timbangan, cup sealer dan plastik.

Bahan yang digunakan pada kegiatan pengabdian masyarakat meliputi; nenas matang, gula pasir, telur ayam, minyak goreng, margarine, baking powder, vanili asam sitrat, garam, butter, terigu, tepung sagu, gelatin bubuk, cengkeh, kayu manis, urea, bibit nata, susu bubuk dan susu kental.

\section{Metode pelaksanaan}

Metode pelaksanaan kegiatan dilaksanakan dalam dua tahapan, yaitu penyuluhan dan praktek pembuatan produk (demontrasi produk). Penyuluhan dilakukan pada seluruh peserta, termasuk menjelaskan proses kerja pembuatan produk secara menyeluruh. Pada tahapan pembuatan produk, peserta dibagi menjadi 5 kelompok untuk membuat produk yang berbeda dan pengemasan produk dengan pengawasan tim pelaksana. Pada akhir kegiatan, peserta mengisi kuisioner yang disiapkan tim pelaksana dan mendapat hibah seluruh peralatan yang digunakan sebagai modal keberlajutan kegiatan.

\section{HASIL DAN PEMBAHASAN}

\section{Hasil}

Dalam pelaksanaan kegiatan dilaksanakan pembuatan enam (6) produk olahan nenas. Pada akhir kegiatan, dilakukan pengisian kuisioner untuk 25 peserta yang mengikuti kegiatan. Hasil kuisioner diuraikan pada tabel 1, 2 dan 3 .

Tabel 1. Ketrampilan peserta mengolah produk kuliner sebelum kegiatan

\begin{tabular}{lcccccc}
\hline Produk & $\begin{array}{l}\text { Sirup } \\
\text { nenas }\end{array}$ & $\begin{array}{l}\text { Keripik } \\
\text { nenas }\end{array}$ & $\begin{array}{l}\text { Selai } \\
\text { nenas }\end{array}$ & $\begin{array}{l}\text { Permen } \\
\text { nenas }\end{array}$ & $\begin{array}{l}\text { Cake } \\
\text { nenas }\end{array}$ & $\begin{array}{l}\text { Nata de } \\
\text { pina }\end{array}$ \\
\hline Keterangan peserta & 0 & 5 & 4 & 0 & 5 & 0 \\
\hline Terampil & 25 & 20 & 21 & 25 & 20 & 25 \\
\hline Tidak terampil & & & & & &
\end{tabular}

Tabel 2. Ketrampilan peserta mengolah produk kuliner sesudah kegiatan

\begin{tabular}{lcccccc}
\hline Produk & $\begin{array}{l}\text { Sirup } \\
\text { nenas }\end{array}$ & $\begin{array}{l}\text { Keripik } \\
\text { nenas }\end{array}$ & $\begin{array}{l}\text { Selai } \\
\text { nenas }\end{array}$ & $\begin{array}{l}\text { Permen } \\
\text { nenas }\end{array}$ & $\begin{array}{l}\text { Cake } \\
\text { nenas }\end{array}$ & $\begin{array}{l}\text { Nata de } \\
\text { pina }\end{array}$ \\
\hline Keterangan peserta & 25 & 25 & 25 & 25 & 25 & 25 \\
\hline Terampil & 0 & 0 & 0 & 0 & 0 & 0 \\
\hline Tidak terampil & 0 & & &
\end{tabular}

Tabel 3. Pendapat peserta tentang produk yang dihasilkan

\begin{tabular}{lcccccc}
\hline Produk & $\begin{array}{l}\text { Sirup } \\
\text { nenas }\end{array}$ & $\begin{array}{l}\text { Keripik } \\
\text { nenas }\end{array}$ & $\begin{array}{l}\text { Selai } \\
\text { nenas }\end{array}$ & $\begin{array}{l}\text { Permen } \\
\text { nenas }\end{array}$ & $\begin{array}{l}\text { Cake } \\
\text { nenas }\end{array}$ & $\begin{array}{l}\text { Nata de } \\
\text { pina }\end{array}$ \\
\hline Keterangan peserta & 25 & 24 & 21 & 25 & 23 & 10 \\
\hline MBE & 0 & 1 & 4 & 0 & 2 & 15 \\
\hline TMBE & & & & &
\end{tabular}

Keterangan:

MBE adalah menarik dan bernilai ekonomi

TMBE adalah tidak menarik dan tidak bernilai ekonomi 

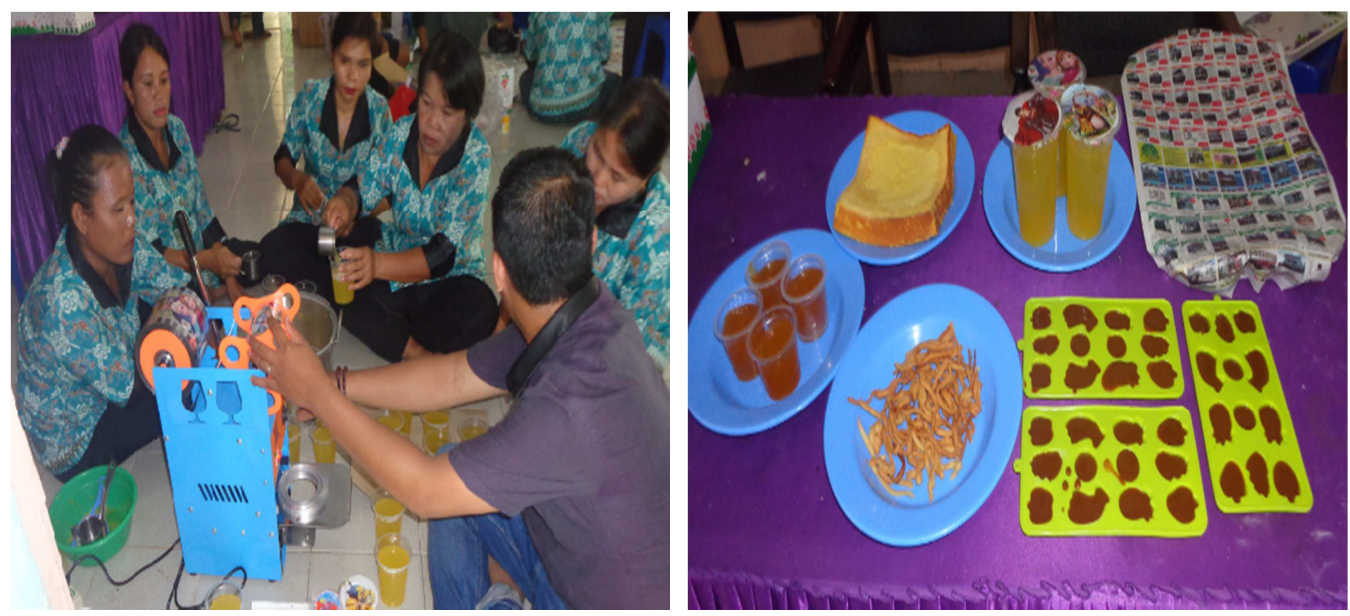

Gambar.1 Kegiatan produksi dan 6 produk yang dihasilkan

\section{Pembahasan}

Kegiatan pengabdian kepada masyarakat ini menjadi wadah bagi masyarakat Desa Dema untuk mendapatkan pendidikan singkat dalam pengembangan ketrampilan pengolahan nenas. Harapan yang ingin dicapai yaitu peserta terampil mengolah nenas menjadi produk pangan yang menarik dan bernilai ekonomi.

Sebelum kegiatan dilaksanakan, peserta tidak terampil bahkan tidak mengenal produk sirup nenas, permen nenas dan nata de pina (tabel. 1). Terdapat $20 \%$ peserta pernah membuat produk keripik nenas, selai nenas dan cake nenas (tabel.1) walaupun ternyata hasil produknya tidak sebaik produk pada saat pelatihan. Keripik dan cake yang pernah dibuat oleh $20 \%$ peserta tidak beraroma dan rasa nenas yang merupakan komoditi lokal Desa Dema. Untuk selai nenas, tekstur dan rasanya lebih baik pada produk saat pelaksanaan pelatihan dikegiatan pengabdian kepada masyarakat. Ketrampilan yang didapatkan peserta pada saat pembuatan selai yaitu konsentrasi gula pada bahan nenas dan pengecilan ukuran bahan nenas yang baik. Untuk produk keripik dan cake nenas, peserta mengetahui bagaimana dan berapa banyak nenas yang harus dicampurkan dalam adonan sehingga didapatkan keripik nenas dan cake nenas dengan citra rasa dan aroma nenas yang tepat. Pada produk permen dan sirup nenas serta nata de pina, peserta peserta memperoleh pengetahuan dan ketrampilan baru yang dapat dikembangkan dalam rangka memperdaya komoditi lokal Desa Dema. Hasil dari pelatihan, seluruh peserta dalam kelompok kecil yang beranggotakan lima orang setiap kelompok dapat memproduksi dan memiliki kemampuan membagikan ketrampilan pada kelompok lain dengan baik (tabel. 2 dan gambar.1).

Produk kuliner olahan nenas yang dibuat diharapkan menarik secara fisik (tekstur), citra rasa, warna dan aroma sehingga memiliki pontensi untuk dijual. Pada kegiatan pengabdian kepada masyarakat ini, tim pelaksana mengarahkan peserta untuk menilai produk yang dihasilkan sehingga kelayakan produk tersebut dapat memotivasi peserta untuk pengembangan produk.

Secara umum peserta menyukai produk yang dibuat dalam kegiatan dan menilai bahwa produk memiliki nilai ekonomi. Peserta sangat tertarik dan menilai memiliki nilai ekonomi untuk produk permen dan sirup nenas mencapai $100 \%$ (tabel.3). Peserta sangat tertarik pada produk sirup dan permen nenas karena menganggap produk ini sederhana dalam pengolahannya dan belum pernah dibuat oleh peserta (tabel.1). Permen dan sirup nenas juga menarik secara fisik, singkat dalam pengolahannya serta memiliki rasa yang khas dan disukai peserta kegiatan. Produk 
yang kurang diminati dan dianggap kurang ekonomi oleh peserta adalah nata de pina. Nata de pina dibuat menggunakan limbah nenas berupa kulit nenas sehingga secara pemanfaatan limbah dianggap menarik. Kondisi lain yang menjadikan nata de pina tidak menarik dan tidak memiliki nilai ekonomi menurut peserta yaitu waktu panen nata de pina yang memerlukan waktu hingga 7 hari dan bahan pendukung seperti stater nata (acetobacter Xylinum) yang sulit didapatkan dan mahal menurut peserta.

\section{KESIMPULAN}

Berdasarkan evaluasi tim pelaksana kegiatan pengabdian kepada masyarakat, maka dapat disimpulkan:

1. Kegiatan pengabdian kepada masyarakat di Desa Dema berlangsung sesuai rencana dengan dukungan mitra kerja dan pejabat Desa.

2. Peserta sebagai mitra kerja dapat menguasai seluruh proses pengolahan produk yang disampaikan saat pelaksanaan kegiatan oleh tim pelaksana Politeknik Negeri Pontianak.
3. Peserta sebagai mitra kerja memiliki kemampuan dalam menggunakan dan merawat peralatan produksi.

\section{DAFTAR PUSTAKA}

Badan Pusat Statistik. 2012. Perkembangan Pembangunan Wilayah Kalimantan.

Badan Pusat Statistik Kabupaten Pontinak. 2012. Gambaran Umum Kondisi Daerah.

Nurwati, 2011. Ilmu Pangan. Jakarta. Universitas Indonesia Press.

Rukmana dan Rahmat. 1997. Pengolahan Dan Pasca Panen Nanas. Yogyakarta : Kanisius.

Sibuea dan Posman. 1997. Ilmu Pangan UGM, Lektor Kepala Jurusan THP Unika Santo Thomas SU. Medan 